\title{
INTENTIONS TO APPLY AS INTERNSHIP STUDENTS ON DIGITAL START-UP COMPANIES IN JAKARTA
}

\author{
Liza Agustina Maureen Nelloh \\ Podomoro University \\ liza.nelloh@podomorouniversity.ac.id
}

\begin{abstract}
Human capital plays an important role in explaining organizational performance and survival, not only for well-established firms but also for digital startup companies. However no previous human resource literature, especially on employers' brand, investigates the internship program in the startup digital firms. Our pre-test shows that students are less attracted to apply to startup digital companies. Consequently, this study aims to test students' intention to be on an internship in startup digital companies with its several antecedents (organizational attractiveness, job meaning, organizational attributes, and institutional image). My purposive sampling generates 101 business and management students in Jakarta as my sample. I run Partial Least Square (PLS) to test my hypothesis. The results indicate that organizational attributes do not affect intention to be on an internship and other hypothesis tests exhibit positive results. Further, the findings also show that organizational attributes do not exhibit mediating effect. Overall, the results suggest that digital startup companies cooperate and collaborate with universities, especially business and management departments in research and student projects in order to attract the best students to be on internship on these companies that eventually will improve their performance.
\end{abstract}

Keywords: intention to apply, organizational attractiveness, work meaningfulness, organizational attributes, employer branding.

\begin{abstract}
ABSTRAK
Sumber Daya Manusia memegang peran penting dalam ketahanan dan peningkatan kinerja perusahaan baik berskala besar ataupun berskala startup digital. Akan tetapi, penelitian sebelumnya mengenai sumber daya manusia khususnya merek perekrut yang menguji secara khusus pada program magang yang banyak dilakukan oleh jurusan bisnis dan manajemen atau sejenisnya masih jarang dilakukan. Kemudian, hasil prates menunjukkan rendahnya ketertarikan dan keinginan mahasiswa untuk melamar di perusahaan startup digital. Oleh karena itu, penelitian ini bertujuan untuk menguji intensi melamar calon mahasiswa magang di perusahaan startup digital bersama beberapa antesendennya (ketertarikan organisasi, arti pekerjaan, atribut organisasi, dan citra institusi). Survey purposive sample dilakukan terhadap 101 mahasiswa jurusan bisnis dan manajemen di Jakarta. Partial Least Square (PLS) digunakan dalam penelitian ini untuk menguji hipotesis. Hasil penelitian ini mengindikasikan bahwa atribut organisasi tidak signifikan pengaruhnya terhadap intensi melamar, bersamaan dengan hasil posifitif pada semua uji hipotesis, dan juga membuktikan tidak adanya mediasi variabel atribut organisasi. Hasil penelitian ini menyarankan perusahaan startup digital untuk membina kerjasama dan kolaborasi
\end{abstract}


yang kuat dengan pihak universitas khususnya jurusan bisnis dan manajemen dalam bidang riset dan proyek mahasiswa untuk menarik calon mahasiswa magang yang berkualitas sehingga dapat mencapai kinerja organisasi yang optimal.

Kata Kunci: intensi melamar, ketertarikan organisasi, arti pekerjaan, atribut organiasi, pemerekan perekrut.

\section{INTRODUCTION}

Digital start-ups are growing fast in Indonesia recently. The research team of Techinasia in 2015 reported that there are $\$ 550$ million of funding capital by venture capitals to digital start-ups in Indonesia. Hence, Indonesia has been said as the biggest opportunity of digital or E-commerce business since there are 39 percent growth rate annually and reached 2000s start-ups in 2016 (Freischlad 2015). The growing startups bring trends to Indonesia E-commerce and the development of economy nowadays. Thus, as trends passing through the nation, start-ups are faced big competition in employment market to survive. Most employers as well as digital startups need "intrapreneurs" who are innovative, creative and have most of entrepreneurial traits in order to survive and creating creative enterprise within the ventures (Davila et al., 2006; Urbano et al., 2013; Xie et al., 2015). Digital start-ups nowadays should pursue human capital as the most valuable resource (Xie et al., 2015; Janice and Leosaputro 2014) by developing its employer branding at employment market. Employer branding is at great momentum to the companies to create image and to attract new prospective employees (Chhabra and Sharma 2014; Jain and Bhatt 2015). Besides prospective employees to be attracted in the real employment market, internship is believed to be one of the collaboration programs between universities as pre developing interns as new employees with low cost and technically low risk (Maertz et al., 2014). Internship would also benefit for employer to get new quality graduates in the future and can contribute to the organizational culture (Hurst et al., 2012). This means employer branding not only for well-established companies but also can also be applied in the internship employment market.

To attract new employees in the perspective of employer branding, most of significant studies results use intention to apply as the focus of the research or the dependent variable to be attractive in the employment market (Birgelen et al., 2008; Gomes and Neves 2011; Xie et al., 2015). Intention to apply is believed to be the final stage of organizational attraction in the eyes of new prospective (Gomes and Neves 2011). Thus, Gomes and Neves (2011) also argued that to understand intention to apply of applicants will lead the organization into effective hiring and to get attention in the organizational attraction. This means intention to apply will be significant momentum in the employer branding perspective to attract high quality applicant. Some previous studies posited that to get the intention to apply, the applicants should have organizational attractiveness (Gomes and Neves 2011; Birgelen et al., 2008). 
Through the study, work meaningfulness is one psychological state of job characteristics of applicant evaluation toward the company. This means something that the intern can learn from the company and would be the important purpose of internship program of the university (Maertz et al., 2014). Some evidences showed that in addition to work meaningfulness, applicants would have perception toward organizational policies and its benefits, or it is called organizational attributes to predict organizational attractiveness and intention to apply (Gomes and Neves 2011; Ryan et al., 2005). Further, institutional image would be the significant predictor of organizational attractiveness and intention to apply of applicants in the employment marketplace (Janice and Leosaputro 2014).

Despite this fact, some questions remained unaddressed especially in internship employment market to the attraction. This would add more information to the literature review about the relation between internship students with the start-ups as insufficient for academic scholars and practitioners. Some previous studies as stated earlier showed that most of the object used to test employer branding of companies within prospective (students or graduates) are corporate or well-known established companies (Chabbra and Sharma 2014; Jain and Bhatt 2015; Maertz et al., 2014). Thus, this study used preliminary study in twenty undergraduate students of business and management in Jakarta. The result emphasized that the students preferred to have work as intern in big and well-known companies and have a low trust in small medium enterprise or digital start-ups. If so, the strategy of digital start-ups to survive and get "intrapreneurs" among interns will be difficult to achieve. Whereas many business and management students nowadays have collaboration programs with the digital startups, but it seemed that the prospective internship would intent to apply to the wellknown and established companies. Based on this gap, this study aims to test how the digital start-ups will attract the intern applicants of business and management students in Jakarta using the stated predictors earlier. This study will benefit to all digital startups in Jakarta to survive using human capital as valuable resources and creating enterprising culture in the future.

\section{LITERATURE REVIEW}

\section{Work Meaningfulness, Institutional Image}

Work meaningfulness is the part of The Job Characteristics Theory (Gomes and Neves 2011). The original concept of job characteristics described about perceptions of incumbents toward their job. At this point, job characteristics pursue to develop three psychological conditions such as meaningfulness of work, responsibility, and feedback or knowledge of outcomes (Gomes and Neves 2011). Thus, work meaningfulness is a type of work value, in that workers may find the experience of meaningfulness important in a work environment, or in other words one possible outcome of the correspondence between a worker's values and environmental 
reinforcers (Hansen \& Leuty, 2012; Wiersma et al., 2016). This work value is related to sense making factor about job to his or her life (Aguinis \& Glavas 2017). In further, More deeply, work meaningfulness would be seen as incumbents' desirable end state, even while also serving as a factor from the rise of happiness (Wiersma et al., 2016).

Among the three predictors of job characteristics, meaningfulness of work is considered as the main source for intrinsic motivation that can be achieved when a job allows employees to use a variety of skills in performing the job (Wiersma et al., 2016). As main dimension of job characteristic, work meaningfulness predicts organizational attractiveness and intention to apply (Gomes \& Neves 2011). These positive links are related to the sense making factor of value of work to be resulting in organizational attractiveness and behavioural intention (Aguinis \& Glavas 2017). So, the value of work for students is believed to create organizational attractiveness and can influence on job choice intention as internship students. Based on the prior explanation, hypotheses can be conducted as follow:

H1a: work meaningfulness is significantly effect on organizational attractiveness.

H1b: work meaningfulness is significantly effect on intentions to apply as internship student.

\section{Institutional Image, Institutional Image, and Organizational Attributes}

Based on the literature review of image is the net result of the interaction of a persons'beliefs, ideas, feelings and impressions about an object. The object can be many things including company or corporate image in human capital research. Hence, Lemmink et al. (2003) mentioned that Corporate image is often substituted with names such as organisational image or institutional image. Thus, Lemmink et al. (2003) define institutional image as social or public knowledge or general perceptions about a given company. Or in other words, an individual assessment toward company's reputation (Highhouse et al., 2009). The sources of institutional image include comments on a company's news, employment experience, consumer experiences, as well as the positive and negative behaviors of the company itself (Turban and Cable 2003). This means when students would like to apply for internship program would have institutional image not only from prior experience, but also it derives from news, word of mouth about positive and negative behaviors of companies.

The prior research showed that institutional image is significant to the organizational attraction (Wei et al., 2016) and the intention to apply (Kim et al., 2011; Tsai and Yang 2010; Wei et al., 2016). The superior institutional image would bring attraction and intention to apply toward the company compare to those with poorer images (Tsai and Yang 2010; Turban and Cable 2003; Wei et al., 2016. Institutional image would benefit to corporate since the lower knowledge of applicant about 
company and decision making process, they usually rely on their knowledge about a firm's corporate image in assessing whether or not to apply (Wei et al., 2016). This means when intern would like to apply, they will assess their perception of the ventures' image and can be attracted if the ventures have positive image to lead into job choice intentions within the ventures. Furthermore, prior explanations will lead to the second hypotheses as follow:

H2a: Institutional image is significantly effect on organizational attractiveness.

H2b: Institutional image is significantly effect on intention to apply as internship student.

Another exogenous variable to be tested in this study is organizational attributes that refers to perceptions regarding an organization's policies and work conditions (e.g. Roberson et al., 2005; Gomes and Neves 2011). Thus, organization attributes and determinations of fit with an organization require applicants to have specified intention and behavior toward organization's characteristics like diversity, payroll, culture, systems and so on to be compare to personal interest and needs (Roberson et al., 2005). More deeply, the organizational attributes posit applicant perceptions of training that held in the organization, compensation and advancement opportunities. The applicants would see the Organizational attributes by seeing the elements in job vacancy advertisements (Gomes and Neves 2011). Besides, Collins and Stevens (2002) identifies several organizational attributes that commonly used in recruitment such as career perspectives; work environment; stability and job security.

Some previous studies have found that organizational attributes have positive effects on applicant attraction to firms or organizational attractiveness (Roberson et al., 2005; Gomes and Neves 2011). More favorable perceptions of organizations and company's characteristics may enlighten employees' interest in the organization, hence to be related to their intentions to apply to those organizations (Gomes and Neves 2011). This means when students have knowledge about ventures attributes and tend to occurred some positive mindset upon those companies, they tend to have positive attention then tend to apply for the job at the certain company. Furthermore, the third hypothesis would be conducted based on the prior explanations as follow:

H3a: Organizational attributes is significantly effect on organizational attractiveness.

H3b: Organizational attributes is significantly effect on intention to apply as internship student. 


\section{Organizational Attractiveness and Intentions to Apply}

This study include endogenous variables, the first one is called organizational attractiveness that refers to the power that draws applicants attention toward the employer (Highhouse et al., 2009), degree to which a person favorably perceives an organization as a place to work (Wei et al., 2016) or the general perceived desirability of working for an organization (Aiman-Smith et al., 2001). Highhouse et al. (2009) described two dimensions of organizational attractiveness such as internal attractiveness for internal marketing or existing employees and external attractiveness for external candidate. This study employed external attractiveness toward outside candidate from students about their intention toward organization to be influence on intention to apply (Roberson et al., 2005). Besides Roberson, Gomes and Neves (2011) have proven that when applicants attract toward the organization, they tend to apply for the job at certain companies.

Intention to apply is derives from the well-known Theory of Reasoned Action (TRA) that would be strong predictor of real applications for applicants in certain conditions (Gomes and Neves 2011). It concluded that intention to apply would be significant of employer branding and create attraction for the applicants to apply in employment market. Hence, if the intention of apply is positive among individuals resulting positive impact such as organizational survival to get high quality human capital (Gomes and Neves 2011, Xie et al., 2015). Some predictors of intention to apply would be seen in many aspects whether it is direct or indirect. Thus, main predictor of intention to apply is applicant's attraction toward organization (Gomes and Neves 2011; Birgelen et al., 2008; Xie et al., 2015). Hence, the new applicants as internship students would have intention to apply in the ventures if she or he has favorability and attention toward the organizations. These prior explanations posit the fourth hypothesis as follow:

H4: Organizational attractiveness is significantly effect on intention to apply as internship student.

Based on the prior studies results, literature review, conjectures and hypotheses development, this study posited a research model as follow: 


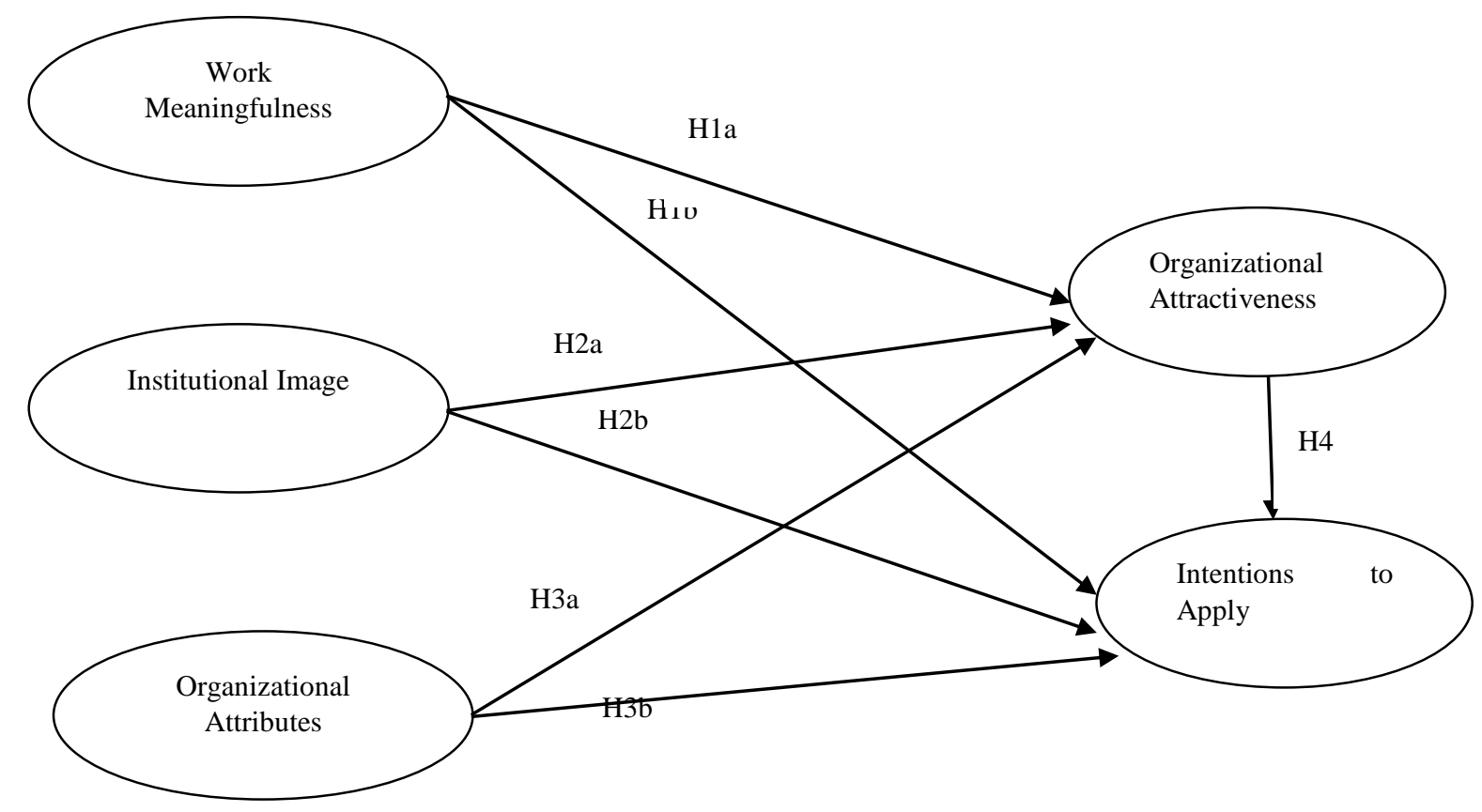

\section{RESEARCH METHOD}

This study used quantitative method through the distribution of a selfadministered questionnaire to 101 business and management students in West area of Jakarta, Indonesia with the purposive sampling technique over a period of two weeks in March 2017. The respondents are choosen as the fifth above semester in business and management majors, with almost or even had experiences as internship students. The distribution of questionnaires were administered during social and community activities, on campus research, and seminar research. A total of 130 questionnaires are distributed, but only 102 were found usable and valid as samples for analysis, and lead to a valid response rate of 78.46 percent. This result is passed the requirements for statistical analysis and described that recommended sample size for a study should be above 100, and if possible, above 200 (Hair et al., 2010; Bagozzi and Yi 2012).

The questionnaires were design using seven-point Likert Scale ranging from ( $1=$ completely disagree, $2=$ disagree, $3=$ Somewhat disagree, $4=$ Neutral, $5=$ Somewhat agree, $6=$ Agree, $7=$ Completely agree). This study consist of two gneral sections in the questionnaire. The first section encompassed general demographic questions and general knowledge of digital startup companies. So, it consist gender and age or demographic. Thus, the respondents were asked whether they knew the digital startup companies such as Go-Jek (an online transportation platform), Tokopedia (marketplace platform), Ralali.com (B2B E-commerce), Taralite (Financial Technology), Sejasa.com (Service marketplace). These startups were selected based on the representatives of industries where the start-ups took place. However, none of the digital start-ups mentioned were given notes. So, if the respondents chose "no", the respondent could not continue to the section B such as variables to be tested. Work 
meaningfulness was measured using three items adapted from Gomes and Neves (2011). Next, another three items were measured to institutional image that adapted from Kaur and Soch (2013). The study of Gomes and Neves (2011) was also adapted to be designed in organizational attributes (three items), and organizational attractiveness (three items). Thus, there were three items of intention to apply to be measured and adapted from Birgelen et al. (2008).

To test the hypotheses, the data was analyzed by Partial Least Squares (PLS) method, which is a variance based technique for the analysis of structural equation modeling (SEM). As analytical tool, this study employed The SmartPLS software version 2.0 was used to assist in the data analysis, as research data is powerful to use smaller sample size with less sensitive toward classical assumption than other covariance approaches like Amos or Lisrel (Henseler and Sarstedt 2013).

\section{RESULTS AND DISCUSSION}

\section{Respondents' Profile}

The respondents' profile would be seen in Table 1. Table 1 presents the basic demographic data in this study and the knowledge of digital start-ups in order to achieve purposive sampling technique. This concluded that mainly respondents are female (55 percent) compare to make (45 percent). Thus, age 21 to 25 played dominantly in this study ( 84 percent), above 26 years old at the second which is 11 percent, and 17 to 20 only contains 5 percent. Table 1 also proofs that 100 percent respondents knew about digital start-ups companies in Jakarta, Indonesia.

Table 1

Respondents' Profile

\begin{tabular}{lcc}
\hline Characteristics & Total & $\begin{array}{c}\text { Percentages } \\
\text { Total=102 } \\
\text { Respondents }\end{array}$ \\
\hline Gender & 101 & \\
Male & 45 & $45 \%$ \\
Female & 56 & $55 \%$ \\
Ages & & \\
$17-20$ & 101 & $5 \%$ \\
$21-25$ & 5 & $84 \%$ \\
$>26$ & 85 & $11 \%$ \\
Knowledge of digital start-ups & 11 & \\
Yes & & $100 \%$ \\
No & 101 & $0 \%$ \\
\hline
\end{tabular}




\section{Descriptive Statistics}

The study used descriptive statistics to see the basic respond of respondents. Table 2 presented the results of the descriptive statistics for each variable. The table posits that all the variables have the mean which is above 4 and standard deviation consisting didn't equal to 2 . This means that mostly the respondents agreed with all of the questionnaires items to measure the variables in this study. From Table 2, it is concluded that most respondents preferred on organizational attributes (mean: 5.52; SD: 1.15). Thus, it is followed by intention to apply (mean:5.50.; SD: 1.20), work meaningfulness (mean: 5.40; SD: 1.16), institutional image (mean: 5.38; SD: 1.18) and organizational attractiveness (mean: 5.30; SD: 1.17).

Table 2

Descriptive Statistics Result

\begin{tabular}{|c|c|c|c|c|}
\hline \multirow{2}{*}{ Variables } & \multicolumn{2}{|c|}{ Actual Score } & \multirow{2}{*}{ Mean } & \multirow{2}{*}{$\begin{array}{c}\text { Std. } \\
\text { Deviation }\end{array}$} \\
\hline & Minimum & Maximum & & \\
\hline Work meaningfulness & 2 & 7 & 5.403 & 1.162 \\
\hline Institutional Image & 1 & 7 & 5.383 & 1.181 \\
\hline Organizational Attributes & 3 & 7 & 5.525 & 1.157 \\
\hline Organizational Attractiveness & 2 & 7 & 5.307 & 1.175 \\
\hline Intention to Apply & 2 & 7 & 5.502 & 1.203 \\
\hline
\end{tabular}

\section{Validity and Reliability Test}

This section will explain validity and reliability in PLS through latent construct in reliability, and validity test through convergent validity and discriminant validity. Firstly, latent construct in reliability through internal composite reliability (Henseler and Sarstedt 2013). The ICR values should exceed the 0.60 (White et al, 2003). Table 3 presents all of constructs contains 0.6 and proof that these variables passed the requirement of reliability analysis.

Secondly, to assess convergent validity were verified by standardized loading factor and average variance extracted (AVE). Hair et al. (2010) requires the standardized loading factor must be greater than 0.6 that each items has a significant $\mathrm{t}$-value at the $\mathrm{p}<0.001$ level (t-statistics >1.96). Thus, the requirement value for AVE must be greater that 0.5 (Hair et al., 2010). Table 3 indicates that all of indicator to measure each of its constructs contained the values that greater than 0.6 and showed that all of the t-statistics are greater than 1.96 to proof that all of measurement items were well loaded on their own constructs. Thus, all of the values of AVE are greater than 0.5 that concluded that this study showed a strong convergent validity within the constructs. 
Table 3

The Reliability and Convergent Validity Result

\begin{tabular}{|c|c|c|c|c|c|}
\hline Variables & Indicators & $\begin{array}{l}\text { Standardized } \\
\text { loading factor }\end{array}$ & $\begin{array}{c}\text { T- } \\
\text { statistics }\end{array}$ & $\begin{array}{c}\text { Internal } \\
\text { Composite } \\
\text { Reliability } \\
\text { (ICR) }\end{array}$ & $\begin{array}{c}\text { Average } \\
\text { Variance } \\
\text { Extracted } \\
\text { (AVE) }\end{array}$ \\
\hline $\begin{array}{l}\text { Work Meaningfulness } \\
\text { (Gomes \& Neves, 2011) }\end{array}$ & $\begin{array}{l}\mathrm{x} 1.1 \\
\mathrm{x} 1.2 \\
\mathrm{x} 1.3\end{array}$ & $\begin{array}{l}0.793 \\
0.748 \\
0.786\end{array}$ & $\begin{array}{l}13.356 \\
14.718 \\
10.189\end{array}$ & 0.820 & 0.603 \\
\hline $\begin{array}{l}\text { Institutional Image } \\
\text { (Kaur \& Soch, 2013) }\end{array}$ & $\begin{array}{l}\mathrm{x} 2.1 \\
\mathrm{x} 2.2 \\
\mathrm{x} 2.3\end{array}$ & $\begin{array}{l}0.822 \\
0.804 \\
0.748\end{array}$ & $\begin{array}{c}17.121 \\
13.279 \\
9.112\end{array}$ & 0.834 & 0.627 \\
\hline $\begin{array}{l}\text { Organizational Attributes } \\
\text { (Gomes \& Neves, 2011) }\end{array}$ & $\begin{array}{l}x 3.1 \\
x 3.2 \\
\text { x3.3 }\end{array}$ & $\begin{array}{l}0.789 \\
0.832 \\
0.785\end{array}$ & $\begin{array}{l}16.826 \\
14.277 \\
10.018\end{array}$ & 0.844 & 0.644 \\
\hline $\begin{array}{l}\text { Organizational Attractiveness } \\
\text { (Gomes \& Neves, 2011) }\end{array}$ & $\begin{array}{l}\mathrm{y} 1.1 \\
\mathrm{y} 1.2 \\
\mathrm{y} 1.3\end{array}$ & $\begin{array}{l}0,802 \\
0,878 \\
0.799\end{array}$ & $\begin{array}{l}13.138 \\
31.286 \\
16.158\end{array}$ & 0.866 & 0.685 \\
\hline $\begin{array}{l}\text { Intentions to Apply } \\
\text { Birgelen et al (2008) }\end{array}$ & $\begin{array}{l}\text { y2.1 } \\
\text { y2.2 } \\
\text { y2.3 }\end{array}$ & $\begin{array}{l}0.802 \\
0.878 \\
0.799\end{array}$ & $\begin{array}{l}25.245 \\
32.787 \\
16.962\end{array}$ & 0.883 & 0.716 \\
\hline
\end{tabular}

Thirdly, to assess the discriminant validity, the measurements of construct of cross loadings were used (Hair et al., 2010). So, if the measurement items of its construct correlation are greater than the size of the other constructs, then this indicates that the latent constructs predict the size of the specified block better than any other block size (Hair et al., 2010). Table 4 posits the result of cross loading analysis. To make the analysis easier, the researcher put the grey blocks to identify the value of each correlation between items at the grey blocks.

The result of discriminant validity showed that the correlations between measurement items of work meaningfulness $(\mathrm{x} 1.1, \mathrm{x} 1.2, \mathrm{x} 1.3)$ are greater than its correlation with other measurement items of institutional image, organizational attributes, organizational attractiveness, and intentions to apply. Thus, the measurement items of institutional image $(\mathrm{x} 2.1, \mathrm{x} 2.2, \mathrm{x} 2.3)$ are greater than its correlation with other measurement items of work meaningfulness, organizational attributes, organizational attractiveness, and intentions to apply. As well as the measurement items of organizational attributes $(x 3.1, x 3.2, x 3.3)$ are greater than its correlation with other measurement items of work meaningfulness, institutional image, organizational attractiveness, and intentions to apply. The measurement items of organizational attractiveness as endogenous construct (y1.1, y1.2, y1.3) are greater 
than its correlation with other measurement items of work meaningfulness, institutional image, organizational attributes, and intentions to apply. Finally another endogenous construct in this study (y1.1, y1.2, y1.3) that are measured intentions to apply are greater than its correlation with other measurement items of work meaningfulness, institutional image, organizational attributes, and organizational attractiveness.

The result of cross loadings analysis posits that there is strong discriminant validity among the constructs. From this section, it can be concluded that this study passed the validity and reliability test.

\section{Goodness of Fit Index}

In PLS, to test the Goodness-of-Fit index ( $\mathrm{GoF})$ of the model can be understood as the geometric mean of two types of R2 values' averages such the average communality and R2 inner such as the average R2 of the endogenous latent variables (Henseler and Sarstedt 2013). Thus, Wetzels et al. (2009) set the three segments of the GoF index: small $(0,1<\mathrm{GoF}=0,25)$; medium $(0,25<\mathrm{GoF}=0,36)$, and large $(\mathrm{GoF}>$ 0,36 ). This study contained 0,752 , which indicates a large Goodness-of Fit index and that the model has better explaining power in comparison with the baseline values defined above. Thus, the model is proven as validating the PLS model globally (Tenenhaus et al., 2004).

\section{Structural Model}

At the second stage of PLS analysis or in other words the structural model, was examined to test the research hypotheses of this study. Blindfolding procedure is required to test predictive capability by seeing R-square to be greater than 0 (Henseler and Sarstedt 2013). As GoF analysis earlier, it is concluded that this study contained predictive relevance which exceeded minimum level of 10 percent suggested by Falk and Miller (1992). Or in other words, all exogenous variables (work meaningfulness, institutional image and organizational attributes) are explained 39.7 percent to organizational attractiveness. Hence organizational attractiveness explained 58.9 percent of the construct of intentions to apply. Furthermore, this study employed bootstrapping resampling technique with 500-sub samples to test influence of exogenous variables on endogenous variables. Through the inner model analysis, the current research model can be assessed by statistical of path coefficient or t-statistics from one variable to another.

The result of path coefficient would be seen in Table 5, Figure 2, and Figure 3. Table 5, Figure 2, and Figure 3 indicates that work meaningfulness is seen to have a significant and positive influence on organizational attractiveness $(\beta=0.215, \mathrm{~T}$ statistics=2.132), and intentions to apply $(\beta=0.225$, T-statistics=2.533). Hence, H1a and $\mathrm{H} 1 \mathrm{~b}$ are supported. In similar, institutional image is significantly and have positive influence on organizational attractiveness $(\beta=0.327$, $\mathrm{T}$-statistics $=3.615)$, and intention to apply $(\beta=0.242$, T-statistics $=2.467)$, inferring that $\mathrm{H} 2 \mathrm{a}$ and $\mathrm{H} 2 \mathrm{~b}$ are also supported. 
Thus, organizational attributes have positive and significant influence on organizational attractiveness $(\beta=0.216$, T-statistics $=2.102)$ but insignificant to predict intentions to apply $(\beta=0.153$, T-statistics= 1.348$)$ and inferred that $\mathrm{H} 3 \mathrm{a}$ is supported and $\mathrm{H} 3 \mathrm{~b}$ is not supported. $\mathrm{H} 4$ is supported due to the statistical result $(\beta=0.329$, Tstatistics=2.767).

Table 5

Statistical Result of Structural Model

\begin{tabular}{llccc}
\hline & \multicolumn{1}{c}{ Hypotheses } & $\begin{array}{c}\text { Path } \\
\text { coefficient }\end{array}$ & $\begin{array}{c}\text { T- } \\
\text { statistics }\end{array}$ & Result \\
\hline H1a & Work Meaningfulness -> Organizational Attractiveness & 0.215 & 2.132 & Supported \\
H1b & Work Meaningfulness -> Intentions to Apply & 0.225 & 2.533 & Supported \\
H2a & Institutional Image -> Organizational Attractiveness & 0.327 & 3.615 & Supported \\
H2b & Institutional Image -> Intentions to Apply & 0.242 & 2.467 & Supported \\
H3a & Organizational Attributes -> Organizational Attractiveness & 0.216 & 2.102 & Supported \\
H3b & Organizational Attributes -> Intentions to Apply & 0.153 & 1.348 & Not supported \\
H4 & Organizational Attractiveness -> intentions to apply & 0.329 & 2.767 & Supported \\
\hline
\end{tabular}

Significant level of $p=0.05$ (T-statistics $\geq 1.96)$

\section{Discussions}

This study assessed the intentions to apply as internship students in digital startups. Intentions apply is influenced by exogenous variables such as work meaningfulness, institutional image and organizational attributes. Thus, it is also influenced by another endogenous variable (organizational attractiveness). In general, the PLS approach support all measurement model and support most of structural model except for H3b was not supported in this study. Specifically, using PLS approach resulting acceptance of $\mathrm{H} 1 \mathrm{a}$ and $\mathrm{H} 1 \mathrm{~b}$. Where work meaningfulness as dimension of job characteristics have significance and positive influence on organizational attractiveness (H1a), thus work meaningfulness have significance and positive influence on intention to apply (H1b). For the positive link on organizational attractiveness and intention to apply is accordance to the previous study results (Gomes and Neves 2011; Aguinis and Glavas 2017). This means work meaningfulness as the value of work as internship students must be maintained on the perspective of students and universities. These also related to the insights that students are attracted to digital startup and tend to apply for the job if they have a chance in internship program. The demographic data in this study inferred that most of the respondents are female students. Based on CNN data, most of users of digital start-ups Indonesia are young female that indirectly related to the awareness of the ventures that lead to the work values in the certain ventures (Aguinis and Glavas 2017). 


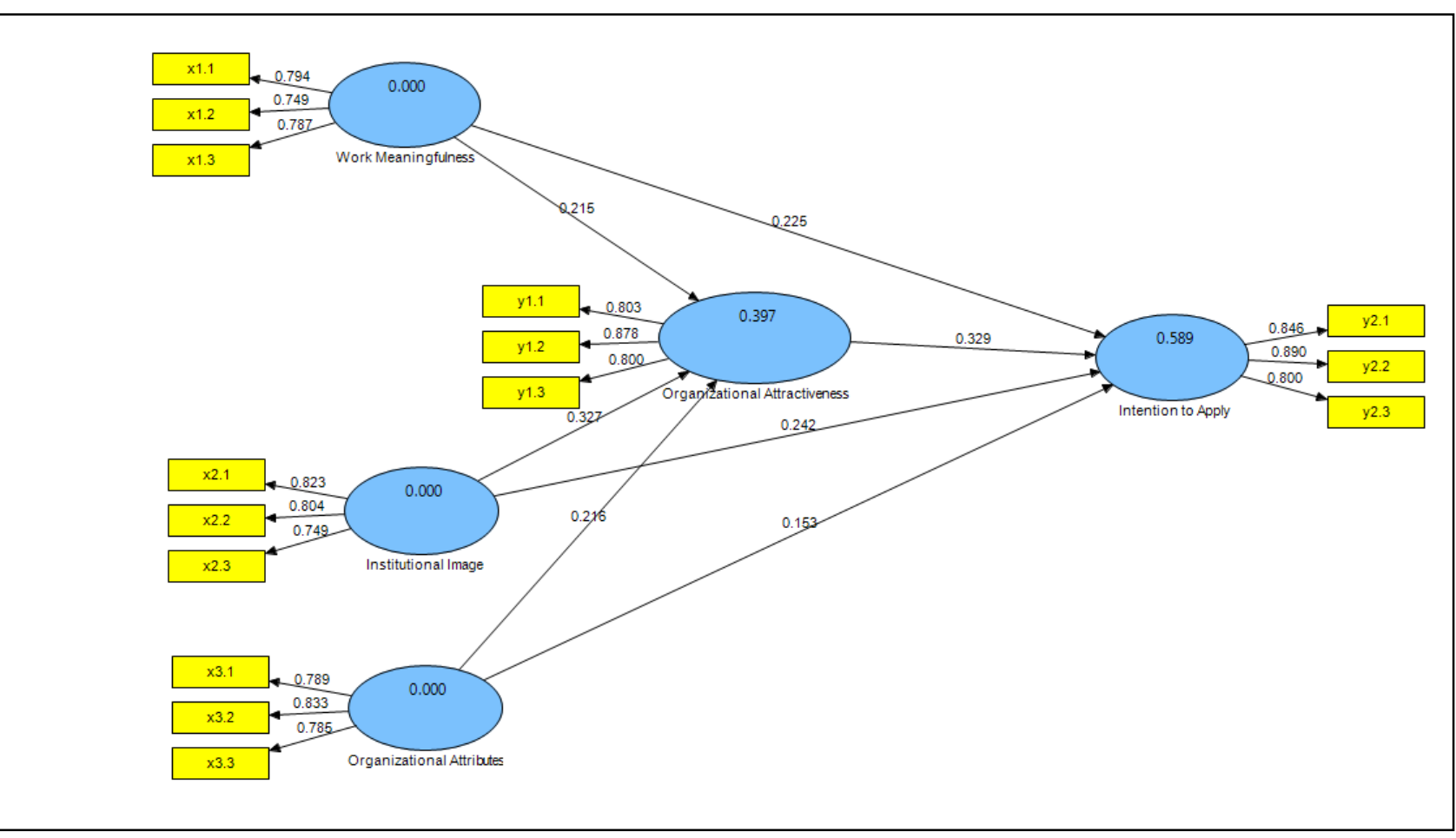

$* P$-values (sig. $5 \%$ ) with T-values $(\geq 1.96)$

Figure 2

Structural Model with Path Coefficien

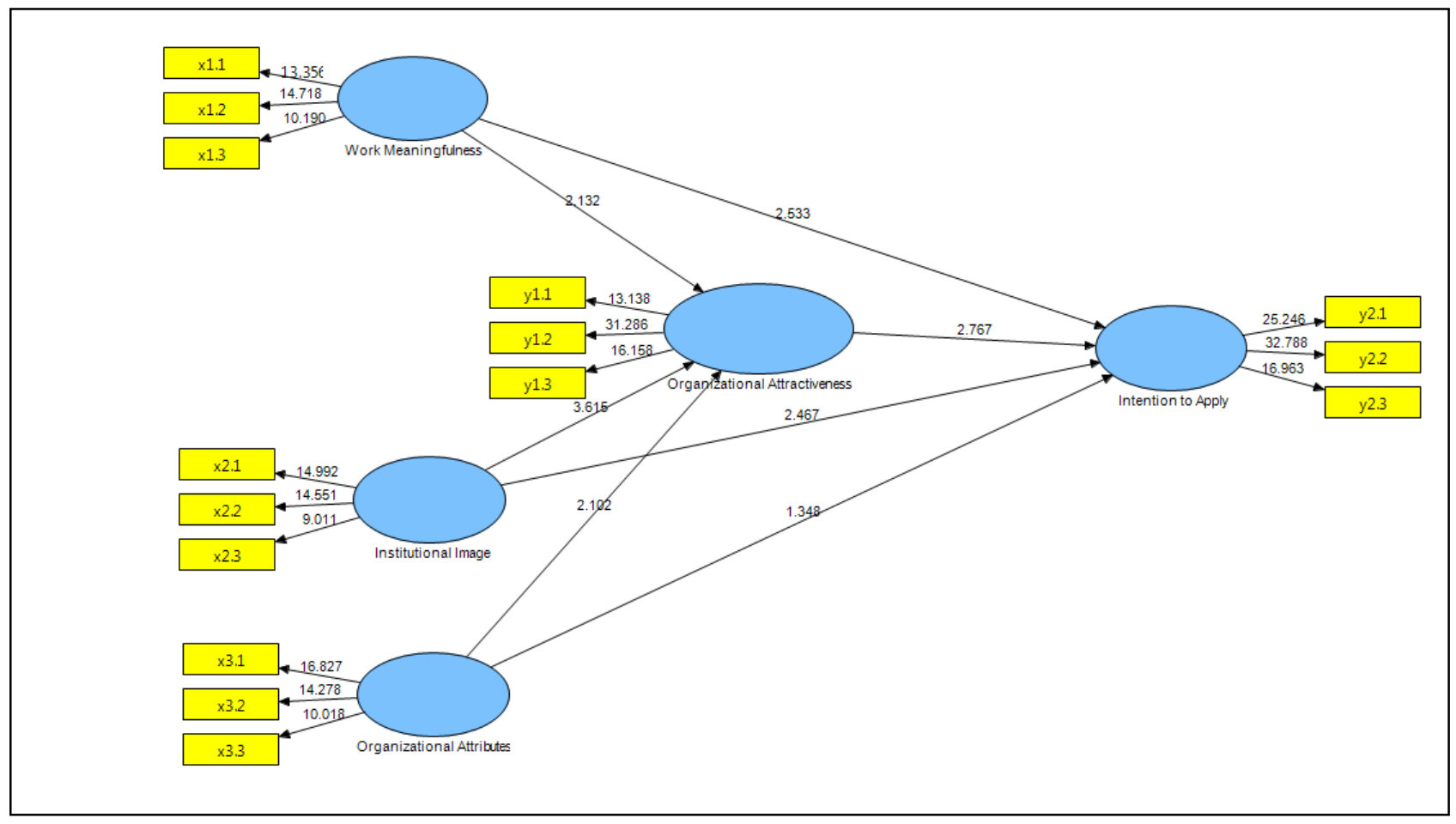

*P-values (sig. 5\%) with T-values $(\geq 1.96)$

Figure 3

Structural Model with T-Statistics 
PLS approach was also yielding the positive link between institutional image and organizational attractiveness $(\mathrm{H} 2 \mathrm{a})$, thus institutional image significantly influence on intentions to apply $(\mathrm{H} 2 \mathrm{~b})$. The acceptance of $\mathrm{H} 2 \mathrm{a}$ and $\mathrm{H} 2 \mathrm{~b}$ are accordance to the previous study results where institutional image is significant to the organizational attraction (Wei et al., 2016) and the intention to apply (Kim et al., 2011; Tsai and Yang 2010; Wei et al., 2016). This means institutional image is considered for internship students to get their attention toward organizations and considered to apply as internship in digital start-ups. This also supported the employer branding perspective (Xie et al., 2015) of digital start-ups in the eyes of business and management students in Jakarta. As the positive and significant results toward organizational attractiveness and intentions to apply, it would be specifically support that organizations that have superior image would be more favourable and attractive, hence increasing job applicant intentions in the employment market compare to the organizations that have poorer images (Tsai and Yang 2010; Turban and Cable 2003; Wei et al., 2016).

Additionally, the quantitative approach using PLS concluded H3a was supported but $\mathrm{H} 3 \mathrm{~b}$ was not supported in this study. The supportive H3a "organizational attributes is significantly influence on organizational attractiveness" is accordance to the previous study results by Roberson et al. (2005) and Gomes and Neves (2011) concluded more favourable perceptions of organizations and company's characteristics will lead to the interest of applicants in the organization. However, Gomes and Neves (2011) found that the more favourable perceptions about organizational attributes will lead to the positive impact on intention to apply in certain organizations, but this study has proven no significant effect of organizational attributes on intention to apply. This result in accordance to Borman et al. (2003), which stated that organizational attributes especially on training or interview would not lead to intention to apply or job applicant intention within the employment market. Empirically, the researcher tried to build a simple interview to the respondents and the result surprisingly provoke that most of female students in this study felt low trust on the attributes of digital start-ups such as accessible of training and learning point of organizational attributes and make them have low intention to apply as internship students. This is related to the statistical result of the lowest standardized loading factor to measure organizational attributes $(\beta=0.785)$. However, as a positive result of attractiveness, most of them agreed that digital start-ups have a strong attractiveness and perceptions nowadays.

Finally, a quantitative PLS approaches yielding a strongly supported result of organizational attractiveness toward intentions to apply as internship students. This result as accordance to the Theory of Reasoned Action that lead to general perceived desirability of working of applicants for an organization (Aiman-Smith et al., 2001). Thus, this positive link is in accordance to Roberson et al. (2005) and the previous study results of Gomes and Neves (2011) and Ryan et al. (2005). At main point, if the 
applicants have more attention and attracted on certain organization, they will tend to apply for the job at the company. This study once again supported the previous study and yielding the insights that if the digital start-ups found out to be attractive in the eyes of prospective internship students, they will apply the job as intern in the digital start-ups. Empirically, based on the simple interview with female students of respondents, they tend to get attention and got attracted toward these companies because the result of CNN data shown that most of young female are active in Ecommerce companies, here it is called digital start-ups.

\section{CONCLUSION}

The findings of this study led to some conclusions in general, for practical implications, and theoretical implications. In general, business and management students are interested and have tendency to apply in digital start-up companies. This study also predicts that employer branding of digital start-up companies will have a good image and reputation in the future, since they have positive branding in the eyes of future employees (university intern students). As human capital plays important role in organizational survival, digital start-up companies should consider about internship collaboration more intensively and effectively than ever before. However, there must be specific recommendations for digital start-up companies about how they will impact on organizational survival that based on human capital in terms of internship programs.

Specifically, the managerial or practical implications of this research led to the insignificant influence of organizational attributes toward intention to apply. As the result shown the lowest standardized loading factor in measuring organizational attributes, the study suggest that digital start-up should improve its employer branding especially in spreading information about its training and other benefits that the intern could have. This could be employees' word of mouth or through the intensive communication between digital start-ups and the universities. If the universities have knowledge about the digital start-up attributes, hopefully the lecturers will communicate it in the classroom during the lecture or seminars. Digital start-ups should also improve its communication about organizational attributes in a collaboration project of research or hands on activities with the students. For instance, small consumer behavior research project with the students and give the chance to students to present their research results to the venture. The human development department should give indirect announcement to the students about the attributes of company. Hence, with increasing the number of collaborations intensively and effectively with the universities such as guest lectures, seminars and workshops, chance for interns or free-lance activities should increase work meaningfulness, institutional image, and organizational attributes hence the students or prospective internship students will have attention and get attracted to the digital start-ups, hence have bigger tendency to apply for the job within the venture in the future. 
The PLS empirical findings not only present in practical implications but also contribute in academic literature especially in employer branding in the perspective of internship program with the university. The statistical results also present that employer branding with human capital that based on organizational survival and performance should also be a part of digital start-ups, not just for multinational or wellestablished companies. Thus, this study confirms six relationships and concluded that work meaningfulness and institutional image would influence organizational attractiveness and intentions to apply as internship students simultaneously along with organizational attributes toward organizational attractiveness, and organizational attractiveness on intentions to apply. This study reject the significant effect of organizational attributes toward intentions to apply that led to specific managerial or practical implications that stated earlier.

Even though this study has many implications for both theoretical and practical, some limitations encountered such as the small number of sample which is only 101 business and management students in West Jakarta territory that cannot generalize the whole population of the fifth or above semester of business and management students in Jakarta. Thus, specifically, the $\mathrm{R}$ squares for this study are relatively low even though it is above $10 \%$ of requirement. There must be additional variables and the increasing number of samples in this study. Finally, this study was not including mediation effect that according to previous study, the organizational attractiveness would be significant to the company reputation if mediation effect is tested between job characteristic, organizational attributes and intentions to apply (Gomes and Neves 2011).

In accordance to the limitations, the further research should include larger number of respondents, if possible between 200 to 500 respondents (Hair et al., 2010) in order to make easier to study to generalize the sample used. Even though PLS can be used to overcome non-normal data, but it is suggested to have high number respondents in the future to get generalization of the variables. Further research can also include other respondents such as fresh graduate students' intention using this structural model research. Thus, since the R-squares are relatively low, the future study should add more variables to tested such as experience of responsibility and knowledge of results (Gomes and Neves 2011), overall website attitude as one significant predictor of organizational attractiveness and intention to apply (Birgelen et al., 2008), person-organizational fit concepts such as identity congruence to make organizational attractiveness (Xie et al., 2015). Finally, the future research is suggested to test organizational attractiveness as mediating role between organizational attributes, job characteristics, and institutional image with intention to apply as internship students. 


\section{REFERENCES}

Aguinis, H., and A. Glavas. 2017. "On corporate social responsibility, sensemaking, and the search for meaningfulness through work". Journal of Management 20(10): 1 - 30. DOI: 10.1177/0149206317691575.

Aiman-Smith, L., T. N. Bauer, and D. M. Cable. 2001. "Are you attracted? Do you intend to pursue? A recruiting policy-capturing study". Journal of Business and psychology 16(2): 219-237.

Bagozzi, R. P., and Y. Yi. 2012. "Specification, evaluation, and interpretation of structural equation models". Journal of The Academy of Marketing Science 40(1): 8-34.

Birgelen, M. J. H. V., M. G. M. Wetzels, and W. M. V. Dolen. 2008. "Effectiveness of corporate employment web sites: How content and form influence intentions to apply". International Journal of Manpower 29(8): 731-751. DOI: https://doi.org/10.1108/01437720810919323

Borman, W. C., D. R. Ilgen, and R. J. Klimoski. 2003. "Handbook of psychology: Industrial and organizational psychology". $12^{\text {th }}$ edition, John Wiley \& Sons Inc.

Chhabra, N. L., and S. Sharma. 2014. "Employer branding: strategy for improving employer attractiveness". International Journal of Organizational Analysis 22(1): 48-60.

Collins, C. J., and C. K. Stevens. 2002. "The relationship between early recruitmentrelated activities and the application decisions of new labor-market entrants: a brand equity approach to recruitment". Journal of applied psychology 87(6): 1121.

Davila, T., M. J. Epstein, and R. D. Shelton. 2006. "The creative enterprise: Managing innovative organizations and people”. Greenwood Publishing Group.

Falk, R. F., and N. B. Miller. 1992. “A primer for soft modeling”. University of Akron Press

Freischlad, N. 2015. "5 years in review: Indonesia's growth in startup funding since 2011". Techinasia. Available at https://www.techinasia.com/ndonesia-startupfunding-up-to-2015

Gomes, D., and J. Neves. 2011. "Organizational attractiveness and prospective applicants' intentions to apply". Personnel Review 40(6): 684-699.

Hair, J. F., W. C. Black, B. J. Babin, and R. E. Anderson. 2010. "Multivariate data analysis: A global perspective”. Seventh Edition, Upper Saddle River, NJ: Pearson. 
Hansen, J. I. C., and M. E. Leuty. 2012. "Work values across generations". Journal of Career Assessment 20(1): 34-52.

Henseler, J., and M. Sarstedt. 2013. "Goodness-of-fit indices for partial least squares path modeling”. Computational Statistics 28(2): 565-580.

Highhouse, S., M. E. Brooks, and G. Gregarus. 2009. “An organizational impression management perspective on the formation of corporate reputations". Journal of Management 35(6): 1481-1493.

Hurst, J. L., L. K. Good, and P. Gardner. 2012. "Conversion intentions of interns: what are the motivating factors?." Education+ Training 54(6): 504-522. DOI: https://doi.org/10.1108/00400911211254280.

Jain, N., and P. Bhatt. 2015. "Employment preferences of job applicants: Unfolding employer branding determinants". Journal of Management Development 34(6): 634-652.

Janice, and J. I. Leosaputro. 2014. "The Impact of Corporate Image of PT XYZ towards Job Applicant Attraction in Surabaya". iBuss Management 2(2): 1220.

Kaur, H., and H. Soch. 2013. "Mediating roles of commitment and corporate image in the formation of customer loyalty". Journal of Indian Business Research 5(1): $33-51$.

Kim, K. H., B. J. Jeon, H. S. Jung, W. Lu, and J. Jones. 2011. "Effective employment brand equity through sustainable competitive advantage, marketing strategy, and corporate image". Journal of Business Research 64(11): 1207-1211.

Lemmink, J., A. Schuijf, and S. Streukens. 2003. "The role of corporate image and company employment image in explaining application intentions". Journal of Economic Psychology 24(1): 1-15.

Maertz, C. P., P. A. Stoeberl, and J. Marks. 2014. "Building successful internships: Lessons from the research for interns, schools, and employers". Career Development International 19(1): 123-142. DOI: https://doi.org/10.1108/CDI03-2013-0025

Maulana, A. 2016. "Nilai transaksi e-commerce di Indonesia menggiurkan". CNN Indonesia. Available at http://www.cnnindonesia.com/teknologi/20160122170755-185-106096/nilaitransaksi-e-commerce-di-indonesia-menggiurkan/

Roberson, Q. M., C. J. Collins, and S. Oreg. 2005. "The effects of recruitment message specificity on applicant attraction to organizations". Journal of Business and Psychology 19(3): 319-339. 
Ryan, A. M., M. Horvath, and S. D. Kriska. 2005. "The role of recruiting source informativeness and organizational perceptions in decisions to apply”. International Journal of Selection and Assessment 13(4): 235-249.

Tenenhaus, M., S. Amato, and V. E. Vinzi. 2004. "A global goodness-of-fit index for PLS structural equation modelling”. Proceedings. XLII SIS Scientific Meeting 1: 739-742.

Tsai, W. C., and I. W. F. Yang. 2010. "Does image matter to different job applicants? The influences of corporate image and applicant individual differences on organizational attractiveness". International Journal of Selection and Assessment 18(1): 48-63.

Turban, D. B., and D. M. Cable. 2003. "Firm reputation and applicant pool characteristics". Journal of Organizational Behavior 24(6): 733-751.

Urbano, D., C. Alvarez, and A. Turró. 2013. "Organizational resources and intrapreneurial activities: an international study". Management Decision 51(4): 854-870.

Wei, Y. C., C. C. Chang, L. Y. Lin, and S. C. Liang. 2016. "A fit perspective approach in linking corporate image and intention-to-apply". Journal of Business Research 69(6): 2220-2225.

Wetzels, M., G. Odekerken-Schröder, and C. V. Oppen. 2009. Using PLS path modeling for assessing hierarchical construct models: Guidelines and empirical illustration. MIS quarterly 33(1): 177-195.

Wiersma, M. L., S. Wright, and B. Dik. 2016. "Meaningful work: differences among blue-, pink-, and white-collar occupations". Career Development International 21(5): 534-551.

Xie, C., R. P. Bagozzi, and K. V. Meland. 2015. "The impact of reputation and identity congruence on employer brand attractiveness". Marketing Intelligence \& Planning 33(2): 124-146. 


\section{APPENDIX}

Table 4

Discriminant Validity

\begin{tabular}{cccccc}
\hline $\begin{array}{c}\text { Measurement } \\
\text { Items }\end{array}$ & $\begin{array}{c}\text { Work } \\
\text { Meaningfulness }\end{array}$ & $\begin{array}{c}\text { Institutional } \\
\text { Image }\end{array}$ & $\begin{array}{c}\text { Organizational } \\
\text { Attributes }\end{array}$ & $\begin{array}{c}\text { Organizational } \\
\text { Attractiveness }\end{array}$ & $\begin{array}{c}\text { Intentions } \\
\text { to Apply }\end{array}$ \\
\hline $\mathbf{x 1 . 1}$ & 0.793 & 0.377 & 0.469 & 0.402 & 0.545 \\
$\mathbf{x 1 . 2}$ & 0.748 & 0.358 & 0.403 & 0.335 & 0.457 \\
$\mathbf{x 1 . 3}$ & 0.786 & 0.487 & 0.426 & 0.440 & 0.394 \\
$\mathbf{x 2 . 1}$ & 0.376 & 0.822 & 0.427 & 0.507 & 0.526 \\
$\mathbf{x 2 . 2}$ & 0.481 & 0.804 & 0.396 & 0.444 & 0.522 \\
$\mathbf{x 2 . 3}$ & 0.387 & 0.748 & 0.395 & 0.332 & 0.408 \\
$\mathbf{x 3 . 1}$ & 0.441 & 0.521 & 0.789 & 0.383 & 0.515 \\
$\mathbf{x 3 . 2}$ & 0.568 & 0.415 & 0.832 & 0.434 & 0.451 \\
$\mathbf{x 3 . 3}$ & 0.324 & 0.282 & 0.785 & 0.394 & 0.395 \\
$\mathbf{y 1 . 1}$ & 0.339 & 0.407 & 0.397 & 0.802 & 0.502 \\
$\mathbf{y} 1.2$ & 0.447 & 0.418 & 0.472 & 0.878 & 0.521 \\
$\mathbf{y 1 . 3}$ & 0.459 & 0.527 & 0.381 & 0.799 & 0.589 \\
$\mathbf{y 2 . 1}$ & 0.526 & 0.521 & 0.412 & 0.588 & 0.846 \\
$\mathbf{y} 2.2$ & 0.485 & 0.499 & 0.504 & 0.558 & 0.890 \\
$\mathbf{y 2 . 3}$ & 0.519 & 0.550 & 0.527 & 0.510 & 0.799 \\
\hline
\end{tabular}

